\title{
«Det er jo lek og læring, sant?»: Konstruksjon av profesjonelle identiteter og kritiske standpunkt
}

\author{
Ole Erik Klinge*, \\ Avdeling for larerutdanning, Høgskolen i Østfold, Halden, Norge
}

\section{Sammendrag}

Samtidig som presset har økt på barnehageinstitusjonen om å innføre tidlig innsats-strategier det siste tiåret, har et stadig større antall norske barnehageforskere funnet det nødvendig å forsvare barns rett til å leke. Mange er kritiske til at formelle læringsmetoder går på bekostning av leken.

I denne artikkelen analyserer jeg intervjuer med norske barnehagelærerstudenter som tok et utenlandssemester i Nicaragua. Jeg vil vise hvordan informantene konstruerte profesjonelle identiteter ved å dikotomisere lek og undervisning/formelle læringsmetoder. Studiet inkluderte tre ukers praksis i lokale barnehager. Artikkelen tar utgangspunkt i intervjuer i forbindelse med informantenes praksiserfaringer. Jeg har fortolket intervjuene ved hjelp av Dorothy Smiths (1978, 2005) sosiologiske perspektiv på språklig konstruksjon.

Informantene distanserte seg fra undervisningsaktiviteter de observerte i de nicaraguanske barnehagene. De identifiserte seg gjennomgående med pedagogikkdiskurser knyttet til nordisk barnehagetradisjon. At dette skjedde er ikke nødvendigvis overraskende. Et interessant trekk ved intervjuene er at informantene utelukket diskurser om økt læringspress i sine beskrivelser av norske barnehager. En viktig side ved artikkelen er måten den viser hvordan identifisering blir gjort, og hvordan fagdiskurser brukes.

Nøkkelord: Barnehagelcererstudenter; formelle laringsmetoder; sosiologi; pedagogikk; Nicaragua

\begin{abstract}
While the pressure on day care institutions to implement early intervention strategies has been immense during the last decade, an increased number of Norwegian kindergarten researchers find it necessary to defend children's right to play. One of the strongest objections is that formal learning methods absorbs time that could have been utilized for playing activities.

In this article I analyse interviews with Norwegian kindergarten teacher students who did a one term course in Nicaragua. I will show how the informants constructed professional identities by dichotomising play and teaching. The studies included three weeks of teacher training practice in local kindergartens. I interpret the interviews through Dorothy Smith's $(1978,2005)$ sociological theories on language construction.

The informants distanced themselves from teaching activities they observed in Nicaraguan kindergartens. Simultaneously, they strongly identified with traditional Nordic pedagogics, in particular children's play as a method of learning. That this happened is not necessarily surprising.
\end{abstract}

^Korrespondanse: Ole Erik Klinge, Avdeling for lærerutdanning, Høgskolen i Østfold, 1757 Halden, Norge, E-post: ole.e.klinge@hiof.no 
An interesting feature of the interviews is that informants excluded discourses on increased learning pressure in their descriptions of Norwegian kindergartens. An important aspect of the article is the way it shows how identification is being done, and how professional discourses are applied.

Keywords: Kindergarten teacher; formal learning methods; sociology; pedagogics, Nicaragua

Received: October 2015; Accepted: April 2016; Published: June 2016

\section{Hva bør en barnehagelærer være?}

I norske pedagogikktidsskrifter er formelle læringsmetoder og tidlig innsats i barnehagen gjennomgående temaer. Kritiske forskere hevder at krav om dokumentasjon, rapportering, testing, kartlegging, tidlig innsats og formelle læringsmetoder/ undervisning har forandret barnehagelærerrollen radikalt i løpet av det siste tiåret ${ }^{1}$. Et sentralt spørsmål i denne sammenhengen er hvorvidt barnehagelærerrollen bør knyttes til formelle læringsmetoder fremfor lek (Pettersvold \& Østrem, 2012; Larsen \& Slåtten, 2014; Sundsdal \& Øksnes, 2015). Temaet er interessant i forbindelse med identitetsforskning, fordi det i vesentlig grad handler om hva barnehagelæreren er eller bør være (Day, 2002; Søreide, 2007).

Artikkelen tar utgangspunkt i intervjuer med elleve norske studenter som tok et semester i flerkulturell pedagogikk og barnehagepraksis i Nicaragua. Informantene brukte ofte fagdiskurser angående lek, læring og undervisning til å sammenligne norske og nicaraguanske barnehagelærere. Deres profesjonelle identiteter og stillingtaken i debatter om lekens rolle ble dermed observerbare. I forbindelse med dette ønsker jeg å svare på problemstillingen: Hvilke barnehagefaglige ${ }^{2}$ diskurser om lek, læring og undervisning brukte informantene til å konstruere profesjonelle identiteter, og hvordan ble konstrueringen gjort?

Artikkelen skiller seg fra andre undersøkelser av identitet og profesjonspraksis ved at intervjusubjektene hadde praksis på et territorium der diskurser de tok for gitt ble utfordret. Det at informantene studerte og hadde barnehagepraksis utenlands, har gjort det mulig å vise hvordan norske identiteter ble konstruerte i lys av andres læringsmetoder.

\section{Konstruering av identiteter}

Artikkelens metodologiske bakteppe er inspirert av den kanadiske sosiologen Dorothy Smith $^{3}$. I tråd med Smith $(1978,2005)$ undersøker jeg hvordan konstruksjon gjøres i

\footnotetext{
${ }^{1}$ De fleste av disse endringene henger sammen med at administreringen av barnehagefeltet har blitt en del av utdanningssystemet.

${ }^{2}$ Jeg bruker en åpen definisjon på «barnehagefaget»: Den omfatter begreper som «barnehagelærerfaget», «barnehagediskurser», «barnehageforskning», «utdanningsdiskurser» og «utdanningsforskning». Fellesnevneren for disse kategoriene er at de kan relateres til barnehagelærerens profesjonelle identitet.

${ }^{3}$ Smith er best kjent som grunnlegger av institusjonell etnografi (IE). Jeg vil i den forbindelse presisere at det ikke er en IE-artikkel jeg har skrevet.
} 


\section{Ole Erik Klinge}

aktiv språkbruk. Når jeg bruker begrepet konstruere, forutsetter jeg at erfaringer er subjektive, og at ingen beskrivelser samsvarer med noen objektiv virkelighet. Ut ifra dette perspektivet er hverken erfaringer eller identiteter lagret i kroppen, men blir til i det øyeblikk det blir satt ord på dem.

Diskurser inneholder ifølge Smith (1978) situasjonsbestemte instrukser ${ }^{4}$ for hvordan virkelighet kan konstrueres. Slike instrukser forteller hva som er akseptable ytringer i spesifikke situasjoner. Dialogpartnere kan velge hvilke diskurser de vil bruke, men konteksten begrenser valgene. Man velger som oftest diskurser ut ifra funksjonene man orienterer seg mot. Autorisering er en vesentlig del av utvelgelsesprosessen. I denne sammenhengen betyr autorisering å instruere, eller lede lytteren til å gjenkjenne en beskrivelse som den rette og godta at motstridende versjoner utelates. Effektiv autorisering betyr at man overbeviser lytteren om at kategoriene som brukes kan tas for gitt (Smith, 1978). Douglas (1966) omtaler fenomener som ikke passer inn i kategorisystemer man tenderer til å ta for gitt som anomalier. En anomali blir ifølge Douglas oppfattet som malplassert materie («matter out of place», Douglas, 1966, s. 48: min oversettelse fra engelsk til norsk). Et eksempel på en anomali er menn som arbeider $i$ et yrke der det er allment forventet at de ansatte er kvinner, eller vice versa.

Katrine Fangen (2006) bruker begrepet distansering om måten somaliere som kom tidlig til Norge konstruerte dikotomier mellom seg og somaliere som immigrerte noen år senere. Hun trekker på Barth (1998), som hevder at anerkjennelse av medlemmer i ens egen gruppe involverer forestillinger om felles kriterier for hva som er rett eller galt. Fangen påpeker at grensene mellom grupper er relative, det vil si at man definerer sin identitet i forhold til de andre:

Å definere hvem man er, handler like mye om å definere hvem man ikke er. Selve det å definere sin identitet via kontraster kan ta form av dikotomisering (Eriksen 1995:434), som vil si etableringen av en bestemt identitet gjennom kontraster vis a vis den andre (Fangen, 2006, s. 10).

Jeg finner Fangens perspektiv anvendbart fordi både hennes og min undersøkelse viser hvordan mennesker som kan defineres som like, konstruerer forskjeller mellom hverandre ved å vise til at man ikke deler de andres verdier.

Jeg har utdanningsbakgrunn i sosiologi og antropologi og hadde liten kjennskap til barnehagediskurser før jeg begynte å intervjue. Jeg ser på intervjuene som et identitetsarbeid (Alvesson, Aschcraft \& Thomas, 2008), der informantene lærte både meg og hverandre måter å konstruere profesjonelle identiteter på. Jeg bruker begrepene instruering og autorisering for å belyse hvordan opplæringen skjedde (Smith, 1978).

\section{Profesjonelle identiteter}

Konstruksjon av profesjonelle identiteter skjer ifølge de australske profesjonsforskerne Trede og McEwen (2012) i skjæringspunktet mellom selvidentifisering, praksisbasert

\footnotetext{
${ }_{4}^{4}$ Jeg bruker begrepet instruks som en metafor. I analysedelen vil jeg vise eksempler på hva begrepet er metafor for, og hvordan instrukser kan brukes.
} 
tilhørighet og institusjonelt fellesskap. Jeg tar utgangspunkt i denne definisjonen når jeg omtaler konstruksjon av profesjonelle identiteter. Dette betyr at jeg ikke skiller mellom individuell og sosial yrkesidentitet (jf. Heggen, 2008).

Trede og McEwen (2012) skriver at profesjonell identitet handler om å være bevisst på sine standpunkt. De mener at utdanning bør klargjøre hva profesjonsfellesskapet forventer at studenter skal stå for. I tråd med dette blir dannelse av felles standpunkter for og imot nye oppgaver en vesentlig del av barnehagelæreridentiteter. Når jeg bruker begrepene nye metoder eller nye oppgaver i artikkelen, sikter jeg til tidlig innsats, kartlegging av barns utviklingsnivå og formelle læringsmetoder/undervisning ${ }^{5}$.

Forskning på profesjonell identitet hos barnehagelærere og debatten om lek versus nye metoder er vevd tett sammen. Larsen og Slåtten (2014) beskriver barnehagelederes profesjonelle identitet som sterkt knyttet til arbeidsoppgavene de finner meningsfulle. De har gjort en undersøkelse med 51 norske barnehagelærere og ledere som viser en tendens til at informantene enten identifiserer seg med nye oppgaver eller tradisjonell barnehagepedagogikk, først og fremst representert ved pedagogens direktekontakt med barna under lekaktiviteter. Forholdet mellom de to gruppene var omtrent halvt om halvt.

Nyutdannede barnehagelærere som kommer ut i jobb vil møte forskjellige, ofte motstridende, teoretiske og hverdagslige diskurser. Hvordan og hvorvidt teori som læres under utdanningen kommer til anvendelse, vil ifølge Steinnes (2010) variere ettersom praktisk kunnskap og dagligdagse diskurser har en sterk posisjon i barnehageinstitusjonen. Vassenden, Thygesen, Bayes, Alvestad og Abrahamsen (2011) skriver at teoretiske begreper blir fortolket på forskjellige måter ute i barnehagene, og at de noen ganger tilpasses for å legitimere bestående praksiser.

\section{Nye og tradisjonelle metoder}

En vanlig dikotomisering i forskningslitteraturen er å beskrive barnehagelærerens nye oppgaver og læringsmetoder som motsetninger til tradisjonell barnehagepedagogikk (Søreide, 2007; Vik \& Hausstätter, 2014). De tradisjonelle barnehagediskursene organiseres rundt begreper som lek og laring, danning, anerkjennelse, medvirkning, omsorg, mangfold og inkludering (Andresen, 2012). Ettersom nordiske pedagogikkforskere har tett kontakt og samarbeid har det blitt skapt en fellesnordisk barnehagetradisjon som setter disse begrepene i høysetet (Alvestad, 2010) (for eksempler, se Emilson \& Folkesson, 2006; Kangas, Ojala \& Venninen, 2015). Selv om forskere, for eksempel Sandvik (2016) og Steinsholt og Øksnes (2003), er kritiske til bruk av lek som middel til å realisere noe som ikke er lek, er det i nordiske fagmiljøer bred enighet om at lek skaper gode betingelser for barns læring og utvikling.

I artikkelen Til forsvar for barns spontane lek argumenterer Sundsdal og Øksnes (2015) for barns rett til å leke. De advarer mot at det «som i utgangspunktet skulle være tid for lek gjøres om til undervisningstid» (Sundsdal \& Øksnes, 2015, s. 6). Deres kritikk kommer også til uttrykk blant andre barnehageforskere (se Barnehageopprop, 2010;

\footnotetext{
${ }^{5}$ Endringene har skjedd parallelt med at barnehagefeltet har blitt en del av utdanningssystemet (Arnesen, 2012).
} 


\section{Ole Erik Klinge}

Andresen, 2012; Arnesen, 2012; Pettersvold \& Østrem, 2012; Sandvik, 2016). Søreide (2007) viser hvordan Utdanningsforbundet, lærere og offentlige dokumenter konstruerer motdiskurser og forsvarer tradisjonelle utdanningsmodeller mot politisk press og innføring av nye metoder. Ifølge Søreide fremstiller Utdanningsforbundet nye metoder som en trend: med andre ord, noe som vil gå over.

Det jeg i denne artikkelen kategoriserer som barnehagens nye oppgaver, er del av en verdensomspennende utdanningspolitisk endringsprosess. OECD ${ }^{6}$ har vært en av de fremste pådriverne for politisk styring av utdanningsfeltet på globalt plan. Cellar og Lingard (2014) hevder at OECDs utdanningspolitikk generelt, og PISA-programmet spesielt, har oppfylt et behov for å kartlegge barns fagnivå på nasjonalt og internasjonalt nivå. De mener at nasjonene trenger å kartlegge sitt utdanningsnivå for å vurdere sin konkurranseevne i en stadig mer globalisert økonomi.

I store deler av den engelskspråklige verden blir politisk styring av utdanningsfeltet mer sett på som en naturlig del av nasjonalstatens utvikling (Cellar \& Lingard, 2014), og blir lettere akseptert blant pedagogiske forskere enn hva som er tilfelle i Norge (Barnehageopprop, 2010; Sandvik, 2016). På den annen side er det mange pedagoger i engelskspråklige land, for eksempel USA, Storbritannia (Day, 2002) og Australia (Sachs, 2001), som oppfatter politisk press for å innføre nye arbeidsmåter som inntrengning på deres profesjonelle territorium. Day (2002) hevder at lærere og lærerorganisasjoner i USA har tatt vel imot nye standarder for formelle læringsmetoder, men at misnøyen med tester og evaluering vokser.

Prinsippet om tidlig innsats står sentralt i debatten om hva barnehagelærere bør være. I 2006 ble tidlig innsats presentert som eget satsningsområde i St.meld.nr. 16 (2006-2007) ... og ingen sto igjen - Tidlig innsats for livslang lcering (Kunnskapsdepartementet, 2007). Teoriene som tidlig innsats-modellene bygger på, er resultater av nevrobiologisk og psykologisk forskning. Litteraturen innenfor feltet er i hovedsak skrevet av amerikanske forskere. Forskerne fremhever at hjernen er mest elastisk og dermed mest mottakelig for læring hos barn fra $0-5$ år. De hevder at det derfor er avgjørende at man investerer $\mathrm{i}$ tverrfaglig og individuelt tilpassede utviklings- og utdanningstilbud til barn i denne aldersgruppen (Vik \& Hausstätter, 2014).

Ifølge Vik og Hausstätter (2014) kan norsk forskningslitteratur om tidlig innsats deles i to kategorier: Den ene har en sosialfaglig vinkling og bygger på angloamerikanske strategiprogrammer (f.eks. Head Start). Den andre kjennetegnes ved kritiske perspektiver på at fremtidsøkonomiske vurderinger brukes som argument for iverksetting av tidlig innsats-strategier i skoler og barnehager (Andresen, 2012; Arnesen, 2012). Mange er bekymret for at barn blir vurdert ut ifra bestemte standarder for hva som er normal utvikling og dermed risikerer å bli stemplet som avvikere (f.eks. Arnesen, 2012; Petterson \& Østrem, 2012; Sandvik, 2016).

\section{Studier og barnehagepraksis i Nicaragua}

Studiet i flerkulturell pedagogikk i Nicaragua ble arrangert av Kulturstudier AS. Studieplanen er godkjent av Høgskolen i Vestfold (2011). Bestått muntlig og skriftlig

\footnotetext{
${ }^{6}$ Organisasjonen for økonomisk samarbeid og utvikling.
} 
eksamen ga 30 studiepoeng som kan inngå i barnehagelærerutdanningen ved norske høgskoler. Studiet inkluderte et tre ukers praksisopphold som ble gjennomført med utgangspunkt i fagplan for praksis ved Høgskolen i Vestfold. Kulturstudiers egne ansatte og lærere fra norske høgskoler foreleste og ledet seminarer. Det var kun et mindretall av studentene som snakket og forstod spansk. De hadde med seg tolk mens de var ute i praksis. Den nicaraguanske rammeplanen for barnehagen (Utdannings-, kultur-, og idrettsministeriet, 2004) er oversatt til norsk og var lagt ut på Kulturstudiers hjemmesider.

Målt etter nasjonalinntekt per innbygger er Nicaragua det nest fattigste landet i Latin-Amerika (Utenriksdepartementet, 2015). Informantene opplevde landet og levestandarden som svært forskjellig fra den de var vant til. Mange uttrykte samtidig at menneskene var imøtekommende og at de tidlig begynte å føle seg hjemme. I motsetning til den nicaraguanske østkysten, som er sterkt påvirket av afro-karibisk kultur, er innflytelsen fra kolonialtiden og spansk kultur fremtredende i de vestlige regionene, der studiet ble arrangert.

\section{Metode}

I løpet av det tre måneder lange studiet i Nicaragua, fra begynnelsen av februar til slutten av april, intervjuet jeg tre av Kulturstudiers ansatte og seksten studenter. Jeg intervjuet tre av studentene tre ganger (to individuelt og én i gruppe); tre ble intervjuet to ganger (én individuelt og én i gruppe). Jeg intervjuet med jevne mellomrom, fra første til siste uke. Elleve av informantene var barnehagelærerstudenter og hadde praksis i lokale barnehager. I denne artikkelen er barnehagediskurser tema; jeg har derfor valgt intervjuene med de sistnevnte som datagrunnlag.

Jeg overvar tretten forelesninger og tok lydopptak under én av dem. Forelesningen jeg registrerte ble holdt en uke etter studiestart. Jeg gjennomførte fire individuelle intervjuer før praksisperioden. Under de innledende intervjuene ønsket jeg først og fremst å finne variasjoner i måter å identifisere oss og dem på. Jeg gjorde ustrukturerte intervjuer; det vil si at jeg ledet studentene inn på temaer ved hjelp av 3-4 forhåndsutvalgte spørsmål. Jeg improviserte spørsmål etter hvert for å holde i gang diskusjoner om temaer jeg ønsket å vite mer om.

Etter praksisperioden intervjuet jeg åtte studenter individuelt og arrangerte fire gruppeintervjuer. I gruppeintervjuene var det i større grad studentene som instruerte meg enn hva som var tilfelle når jeg intervjuet én og én informant. I dette legger jeg at individuelle intervjuer krevde at jeg stilte flere spørsmål for å holde samtalen i gang, mens i gruppeintervjuene gikk dialogen i lengre perioder uten min innblanding.

Charlotte, som tok studiet i Nicaragua som del av sin sosialantropologiutdannelse, ledet et intervju med to av sine medstudenter uten at jeg var til stede. Hensikten med å la henne lede intervjuet var å sammenligne et intervju med bare studenter til stede med dem jeg ledet. Jeg ville undersøke om de samme diskursene ble brukt, og om de eventuelt ble brukt på tilsvarende måter, som når jeg var til stede.

Jeg styrte samtalene i stadig økende grad inn mot mønstre som skilte seg ut i de foregående intervjuene. Et gjennomgående trekk var at informantene brukte 


\section{Ole Erik Klinge}

tradisjonelle nordiske pedagogikkdiskurser til å konstruere forskjeller mellom norske og nicaraguanske barnehagepraksiser. Jeg utarbeidet problemstillingene i denne artikkelen på bakgrunn av dette.

Fordi jeg skulle intervjue studenter som tilhørte en relativt liten gruppe, hadde jeg ikke mulighet til å velge informanter i tråd med formelle utvelgelsesmetoder. Jeg intervjuet alle som sa seg villige til å delta. Det var et stort overtall av kvinner på studiet, og det ble kun to mannlige studenter blant de intervjuede. Intervjuene ble gjort på kafeer og hostelene studentene bodde på. Alle intervjuer ble registrert med diktafon og transkribert. Jeg informerte både skriftlig og muntlig om hva intervjuene skulle brukes til. Informasjon og tiltak for anonymisering er gjort i tråd med anbefalinger fra Norsk samfunnsvitenskapelig datatjeneste.

Jeg brukte en hierarkisk sorteringsmetode for å ordne dataene i kategorier (Sullivan, 2012). Først skilte jeg ut tekstsekvenser i henhold til hvilke temaer de egnet seg til å belyse. Sekvensene kunne være fra noen få strofer og opp til flere titalls linjer, ettersom hvor ofte og i hvilken grad temaene skiftet. I denne artikkelen har jeg brukt sekvenser jeg kategoriserte som utdanning og pedagogisk diskurs.

Etter å ha delt inn intervjusekvenser etter tema, skilte jeg ut tekstdeler som inneholdt sammenligninger mellom Norge og Nicaragua. Neste skritt var å trekke ut lydbiter, det vil si bruddstykker på en til to setninger, av beskrivelser om fenomener informantene var opptatte av (Sullivan, 2012). Ved hjelp av lydbitene kunne jeg identifisere diskursive mønstre og variasjoner. Eksempelet nedenfor viser hvordan jeg organiserte lydbitene i tabeller. Denne tabellen fremstiller hvordan lek, anerkjennelse og medvirkning ble konstruert ved å vise til hva det $i k k e$ er $^{7}$ :

Ikke lek

Ikke anerkjennelse

Ikke medvirkning

$\ldots$ en slags at de sitter ved pultene sine og følger en ... anerkjenne barnet sine svar, mens her var det mer av "det er riktig, det er riktig"...

...de skal gjennom de bokstavene, de skal...

lærer. .

Intervjusitatene er tatt fra tre gruppeintervjuer som ble gjort den siste undervisningsuken. Utdragene der Yvonne er sitert stammer fra Charlottes intervju, de andre er tatt fra dem jeg ledet. Slik jeg ser det, kommer mønstre i det samlede datamaterialet spesielt godt frem i sitatene jeg presenterer. De viser også hvordan diskurser som har fellestrekk ble brukt på forskjellige måter.

Noen steder har jeg utelatt deler av sitatene jeg regner som lite relevante. Jeg har fjernet ufullstendige og irrelevante formuleringer som er vanlige i muntlig språk, men som fremstiller informantene som uartikulerte når de er nedskrevet. I tillegg har jeg forandret på enkelte uttalelser for å gjøre dem mer grammatisk riktige. Tre punktum i hakeparentes markerer tekst som er tatt ut. Ord i hakeparentes betyr at jeg har

\footnotetext{
${ }^{7}$ Her viser jeg kun en lydbit per kolonne, mens tabellene jeg brukte i analysen har fra tre til seksten biter i samme kolonne/kategori. Lydbitene jeg viser, representerer et mønster. Jeg vil presisere at jeg også fant mange lydbiter som avviker fra mønstrene.
} 
forandret intervjuteksten ved å sette inn mine ord. I seks av de ni sitatene jeg bruker, har jeg ikke tatt med intervjuerens spørsmål eller innledning av tema; grunnen er at de aktuelle ytringene i liten grad er svar på spesifikke spørsmål, men heller et resultat av informantenes initiativ.

Jeg har ikke satt meg som mål å gi en objektiv beskrivelse av hva som skjedde da studentene hadde barnehagepraksis. I stedet ser jeg på hvordan informanter brukte diskurser til å konstruere subjektive virkeligheter. Metoden innebærer at man tar det informantene sier på alvor. Dette betyr ikke at de betraktes som sannhetsvitner, men at jeg forsøker å forholde meg objektivt til informantenes subjektiviteter. Jeg følger Smith (2005), og regner forskerens dialog med informanter som en mulighet til å lære hvordan de konstruerer virkeligheter.

\section{Resultat}

Fagbegrepene informantene brukte for å sammenligne nicaraguanske og norske læringsmetoder, har en privilegert posisjon i nordisk pedagogikkdiskurs. Dette eksemplet er fra et intervju Charlotte gjorde med medstudentene Yvonne og Linda:

Charlotte: I forhold til det her så har dere nevnt det her litt begge to, det her med praksis. [Jeg] kunne godt tenkt meg å snakke litt mer om hva den har betydd [...], hvilke opplevelser dere har hatt [...] Vil du starte?

Yvonne: Jeg synes at i starten så var det liksom sånn derre: «herregud hvilken pedagogikk er det de driver med her? Det er ikke anerkjennende, og det er ikke lek. Og egenverdien, og identitet, og barns perspektiv.. ${ }^{8}$ Det var så mye som jeg har liksom lært og tenkt at det her er viktige egenskaper som jeg som førskolelærer ønsker å ha. Så kommer jeg hit og det, jeg var så frustrert. Men nei: «Hei vent! det er én voksen, fem og førti unger, og de har fastsatte daglige mål som de skal rekke gjennom på fire timer på formiddagen før det kommer en ny gruppe som du skal gjøre akkurat det samme med.» Du kan nesten ikke sammenligne det med Norge, for det er helt helt andre forutsetninger. Og så liksom begynner du å tenke på: «Fy fader for en fantastisk dame.»

I første halvdel av sitatet oppsummerer Yvonne funnene jeg presenterer i denne artikkelen. Det den nicaraguanske læreren giør får Yvonne til å tenke på henne som «fantastisk». Hun signaliserer samtidig at hun ville foretrukket at barnehagelærere fulgte idealene hun selv forfekter: anerkjennelse, lek, egenverdi, medvirkning og barns perspektiv. Hun forklarer at nicaraguanske barnehagelærere ikke viser ferdighetene hun «som førskolelærer ønsker å ha», med at de arbeider under vanskelige forhold. Dermed bekrefter hun sitt eget perspektiv, der hjemlig pedagogikk definerer den gode barnehagelæreren.

På den annen side kritiserer Yvonne seg selv og andre som vurderer nicaraguaneres handlinger ut ifra fagdiskurser de har med hjemmefra. Sannsynligvis er hovedbudskapet hennes at man ikke kan betrakte sine egne kulturelle perspektiver som universelle. Hun var opptatt av at barnehagelærere skulle gjøre det pedagogisk «riktige», men

\footnotetext{
${ }_{8}^{8}$ Jeg bruker anførselstegn på denne måten når informanten referer til noe man selv eller andre har sagt tidligere. Jeg tar ingen hensyn til om utsagnene referer til noe som «virkelig» ble sagt eller ikke.
} 


\section{Ole Erik Klinge}

erfarte at hva som var riktig var avhengig av lokale forhold. Det «fantastiske» kan forstås som at nicaraguanske barnehagelærere var svært tilpasningsdyktige, og at dette også er en ferdighet hun ønsket å ha.

Yvonne viste hvilken pedagogisk tradisjon hun identifiserer seg med på en rett frem og åpen måte. Jeg har valgt det neste intervjuutdraget fordi det etter min oppfatning viser at pedagogiske diskurser brukes til tross for at fagbegrepene ikke uttales. Utdraget er hentet fra et gruppeintervju jeg gjorde med Karin, Tove og Lise. Karin beskrev bruk av makt i nicaraguanske barnehager:

Karin: Makt er bare diskurs her nede. Makt, liksom synet på makt for eksempel at når folk gir trusler. Så jeg er helt sikker på at hun læreren tenker ikke at det er stygt, hun tenker nok bare: «Det jeg gjør for å få dem til å roe seg.» Men da vi spurte henne om det liksom, «Hvorfor gjør du det liksom? Føler du det fungerer bare.» «Ja, det er noe som fungerer og.» Så få dem til å tenke over at kanskje, kanskje finnes det andre metoder. Kanskje ta dem i hånden i stedet for og spørre hva er problemet liksom hvis de hopper opp og ned.

Karin forteller om en barnehagelærer som i hennes øyne har gjort noe «stygt» og beskriver hvordan «vi» reagerte. Barnehagelærerens bruk av makt og disiplin (jf. «det jeg gjør for å få dem til å roe seg») kan forstås som at barna ikke får anerkjennelse for sin måte å være på og at de ikke medvirker i utformingen av sin egen hverdag. Metodene og makten læreren brukte for å få barna til «å roe seg», kunne ifølge Karin kanskje ha blitt byttet ut med «andre metoder». Å spørre barna hva «problemet» er, kan bety at man avstår fra maktbruk. Hun fremstiller situasjonen som at det er mulig for oss å få dem til å «tenke over at det finnes andre metoder». I og med at de lokale lærerne ikke kjenner til de andre metodene, mens det er «vi» som vet at de finnes, konstrueres verdiladede skiller mellom våre og deres metoder (Smith, 1978; Barth, 1998; Fangen, 2006).

Intervjudeltakerne kunne velge å utfordre Karins beskrivelse, eventuelt komplettere den. Utsagnene ble imidlertid etterfulgt av et øyeblikks stillhet som varte frem til vi begynte på et nytt tema. At Karin blir stående uimotsagt indikerer at vi anså hennes versjon som gyldig. I tråd med Smith (1978) betrakter jeg dette og de etterfølgende intervjuutdragene som tegn på at informanter brukte et sett autoriserende instrukser for hvordan barnehagelærere kan beskrives. For eksempel instruerer Karin lytterne til å godta at «våre» metoder er gode ved å definere dem som motsetningen til det negative («makt», «stygt», «trusler») den nicaraguanske læreren gjorde. Slike instrukser er ofte avgjørende for om dialogpartnere vil godta en språklig konstruert versjon av virkeligheten.

Jeg har fortolket Karins beskrivelse på bakgrunn av andre utsagn der pedagogikkbegrepene åpent ble brukt til å autorisere:

Tove: Hun var en fantastisk lærer, hun ga hele seg selv [...], og hun hevet aldri stemmen til ungene eller noe som helst. Hun bare anerkjente alle på en veldig fin måte.

Her er det en nicaraguansk barnehagelærer som anerkjenner. Uttalelsen skiller seg fra Karins på dette punktet. Men måten de autoriserer sine versjoner på er like, 
det vil si at anerkjennelse settes opp imot negativ disiplinering (jf. Karin: «få dem til å roe seg» og Tove: «hevet aldri stemmen»).

\section{Dikotomisering av lek og undervisning}

Begreper som anerkjennelse og medvirkning ligger på et forholdsvis abstrakt nivå og kan, som alle andre begreper, fortolkes på forskjellige måter. Å finne ut hvilke konkrete metoder informantene regner som anerkjennende og som lar barn medvirke, kan gi en bedre forståelse av hvordan pedagogikkdiskurser kan brukes til å konstruere identiteter. Lise viser en måte å skille norske og nicaraguanske barnehagelæreridentiteter på:

Lise: Siste dagen så hadde vi forelesning om Norge og hvordan vi gjorde det. [Vi] viste bilder, og da var det liksom sånn: «Hvor lenge får de lov å leke liksom?» «Satt de ute i sandkassen så lenge som de ville?» «Ja, men når lærer de disse tingene da?» [...] så bare: «Nei det går på lær[ing], altså ungene får velge selv hva de vil, og så hjelper vi dem å ha læring inn i leken.» Og de bare: «Guri!»

Utropet «Guri» til slutt i sitatet er sannsynligvis et uttrykk for overraskelse fra de lokale barnehagelærernes side: De forventet ikke at det ble lagt stor vekt på lek i norske barnehager. Lises referering til en barnehagelærer som sier «når lærer de disse tingene», henviser til at nicaraguanerne følger formelle målsettinger for hva barna skal lære, og at det ikke forventes at man lærer «disse tingene» ved å leke. Hun beskriver situasjonen som at vi og de er enige om at våre syn på lekens verdi er motstridende. Lek i norsk versjon og læring i nicaraguansk versjon blir fremstilt som gjensidig utelukkende kategorier, eller med andre ord: dikotomier.

Ved å konstruere identiteter med deres stemmer lar Lise dem bekrefte at det er forskjellige profesjonsfellesskap det er snakk om. Hun giør ikke bare det Fangen (2006) og Barth (1998) mener er et grunnleggende karaktertrekk ved distansering, som vil si å legge vekt på ulikhet mellom oss og de andre; hun bruker også de andres reaksjoner på hennes handlinger til å skape bevissthet om hvem vi er.

I det neste utdraget beskriver Jon og Inga lek i norsk versjon nærmere:

Jon: Jeg spurte hvordan det gikk, og så smilte og løp og, tjo hei liksom, altså, var ikke så veldig mye sånn der formell samtale. Sånn som med læreren på en måte [...] Inga: [De] fortalte bare hva de skulle gjøre. Mens for meg er det veldig naturlig å være med barna, leke med dem, og gjøre det samme, gå på samme nivået. Sant? [...] Så jeg tror at i og med at de gjorde det såpass tidlig så kjente de og at: «å ja, hun kan jeg kanskje leke litt med på en annen måte.»

Undertonen i Ingas fortelling, som jeg forstår som rettet mot hierarkiske forhold mellom barn og voksne, kan være uttrykk for motstand mot at leken blir et middel for å lære. Ved å beskrive hvordan hun tar etter barna, følger deres impulser og kryper med dem, viser hun at barna bestemmer premissene for leken (jf. Steinsholt \& Øksnes, 2003; Sandvik, 2016). Ingas versjon kan oppsummeres med at hun inkluderte («være med»), anerkjente («samme nivået») og lot barna medvirke («være med»og «gjøre det samme»). 


\section{Ole Erik Klinge}

Hun beskriver sin lek med barna som «naturlig». $\AA$ fremstille handlinger som naturlige er en vanlig måte å autorisere på. Man kan kjenne igjen denne formen for autorisering i den forrige rammeplanen for førskolelærerutdanningen. Der er det lagt vekt på at fagene «skal i tillegg til faglig kunnskap gi innsikt $i$ en helhetlig læringsforståelse, der omsorg, lek og læring er naturlige elementer.»(Kunnskapsdepartementet 2006, s.13).

Jon fremhever at den formelle samtalen er et trekk ved den nicaraguanske barnehagelæreren som skiller ham fra den nicaraguanske barnehagelæreren. Inga følger opp Jons ytring og skaper en kontrast mellom nicaraguanske barnehagelærere og seg selv ved å beskrive hvordan hun krøp med barna og lekte «på en annen måte». Hun bruker ordet mens i samme forstand som når man sier $i$ motsetning til: Hun lekte, mens de fortalte. Det å fortelle barna og bestemme hva de skal gjøre, ble ofte brukt som grensemarkør mellom norske og nicaraguanske identiteter:

Tove: Ja, «ta en teipbit, og så, ja nå skal vi lage en firkant, ja nå skal vi lage en trekant». [Så] stiller ungene seg opp. Og så lager de den trekanten eller firkanten, og lærer ut ifra undervisning på gulvet da. Det blir på en måte lek, og det er jo fantastisk.

Det fremgår av sitatet at det er fordi «det blir på en måte lek» at undervisningen blir «fantastisk». Tove nærmer seg en definisjon der dikotomien lek versus undervisning brytes opp. Hun fortolker likevel aktiviteten som forskjellig fra lek i norsk versjon. Bakgrunnen er trolig at barnehagelæreren fortalte og bestemte ${ }^{9}$ at «nå skal vi lage».

Det er også lagt vekt på at lek skal brukes som læringsmetode i den nicaraguanske rammeplanen for barnehagen (Utdannings-, kultur-, og idrettsministeriet, 2004). Dette kan tyde på at nicaraguanske barnehagelærere brukte metoder de kategoriserte som lek.

I tråd med Barth (1998) er det ikke en forutsetning at profesjonsutøvere fortolker faglige verdier og diskurser likt for å regne seg som medlemmer av et profesjonsfellesskap. En like så viktig faktor er forestillinger (tanker, idéer) om at våre verdier skiller seg fra de andres. Det neste intervjuutdraget fortolker jeg som en prosess der lekbegrepet bearbeides for å passe inn i en slik forestilling (jf. Vassenden m.fl., 2011):

Tove: Alt går på undervisning og hjemme er det mer lekbasert og samlingsstunder. Ole Erik (intervjuer): Hva legger du i begrepet samlingsstund?

Karin: Hver dag så har du samlet ungene. Og så skal de høre på ett eller annet sånn i samlingen, om en bjørn eller litt sanger. Bare for å spørre hvordan det går med alle. De leker seg fram. Sant?

Ole Erik: Og når det ikke er samlingsstund, hva skjer da?

Karin: Nei da er det lek.

Ole Erik: Lek?

Lise: Frilek eller aktivitet.

\footnotetext{
${ }^{9}$ Enkelte ganger brukte informantene begrepet bankundervisning for å presisere at barnehagelæreren fortalte og bestemte. I slike tilfeller refererte de til Paolo Freires (2000) teorier. Jeg skriver om studentenes bruk av Freires teorier i en annen artikkel, og går ikke nærmere inn på dette her.
} 
Karin: Det er jo lek og læring. Sant? Altså, det er aldri sånn at nå skal vi sette oss ned og så skal vi lære oss ting, det er jo veldig sjelden.

I både dette og det forrige sitatet er det de voksne som velger ut læringsaktivitetene. Det er derfor interessant å se hvordan Karin beskriver samlingsstunder der barna skal «høre på et eller annet» som lek. Defineringen av lek tar forskjellig form og blir åpnere etter hvert som dialogen går fremover. Karin og Lise fortolker både samlingsstunder og alt som foregår utenom samlingsstundene som lek. Den relativt åpne fortolkningen informantene brukte, kunne talt for at barn i nicaraguanske barnehager også lekte, for eksempel ved å sitte på gulvet og lage geometriske figurer (jf. forrige sitat); men når Karin beskriver «lek og læring» som en kontrast til å sette seg ned «for å lære oss ting», gjør hun en slik versjon mindre sannsynlig.

Karins ytringer kan også forstås som autorisering av kontrasten Tove konstruerer mellom norske og nicaraguanske barnehagepraksiser i sitatets første linje; det vil si: Hun utdyper, forklarer og «lærer» meg hvordan jeg bør forstå begrepene Tove brukte. Dette giør hun sannsynligvis ut ifra en forestilling om at hun og de andre informantene forstår fagbegreper (her: lek, læring, samlingsstund) mer eller mindre likt. Måten hun sier «sant» på, tolker jeg som en kontroll på at jeg betraktet hennes og Toves beskrivelser som gyldige.

\section{Formelle læringsmetoder, politisk press og statlig styring}

Flere av informantene som vurderte de lokale barnehagelærerne som flinke, la vekt på at de jobbet under tidspress. Lise og Karin forklarer hvorfor tidspresset oppstod og hvilke konsekvenser det fikk:

Lise: Så synger vi litt sånn som ungene ønsker da. Men her var det jo læreren som bestemte hva en skulle synge, hva en skulle lese og.

Ole Erik: Fikk dere noe inntrykk av hvorfor de ville bestemme selv?

Lise: De hadde jo den planen da at det. .

Karin: Tid...

Lise: Ja det...

Ole Erik: Tid?

Karin: De har ikke tid til medvirkning rett og slett.

I noen informanters øyne ble nicaraguanske barnehagelærere presset av myndighetene til å undervise for å oppnå bestemte læringsmål:

Inga: Altså vi har rammeplanen så vi kan velge å arbeide ut ifra den hvordan vi vil så lenge vi er innenfor på en måte de rammene. [...] Mens her så har de sånt de skal være gjennom: altså type lære å regne, de skal gjennom de bokstavene. Så sånn sett så virker det som de har mer press her på den måten i forhold til læreplanene.

Slik jeg har vist tidligere, skaper Inga et motsetningsforhold mellom nicaraguanske og norske barnehagepraksiser gjennom måten hun bruker ordet mens på. Ved å beskrive virkeligheten vi må forholde oss til, der man kan «velge», som en motsetning til deres, der man «skal» gå gjennom bokstaver og lære å regne, konstruerer hun en 


\section{Ole Erik Klinge}

norsk barnehage med relativt lite press i forbindelse med formelle læringsmetoder. En alternativ beskrivelse kunne vært gjort ved hjelp av diskurser som brukes i debatten om formelle læringsmetoder i barnehagen. Ved å trekke inn slike diskurser kunne informantene løst opp dikotomiene mellom våre og deres metoder.

Situasjonen Lise, Karin og Inga beskriver, ligner på scenarioet forskere som er kritiske til økt politisk styring av den norske barnehagen advarer mot; lek og barnas mulighet til medvirkning reduseres på grunn av at formelle læringsmetoder får førsteprioritet (jf. Barnehageopprop, 2010; Pettersvold \& Østrem, 2012; Sundsdal \& Øksnes, 2015).

Jeg har kodet og samlet alle utsagn der informantene sammenlignet Norge og Nicaragua. Videre har jeg sortert ut sammenligninger de gjorde i forbindelse med barnehage, skole, læring, pedagogikk, fag og utdanning. Deretter har jeg lett etter åpne og underliggende tegn på at informantene snakket om at politisk press om å bruke tidlig innsats og formelle læringsmetoder/undervisning forekom i Norge. Jeg finner ingen eksempler på at dette skjedde i noen av intervjuene. Dette er tilsynelatende oppsiktsvekkende fordi politisk press om å utføre tester og drive målrettet undervisning i norske barnehager ble diskutert både på forelesninger og i pensum. Intervjuene jeg gjorde, ga meg derimot ingen tydelige tegn på at en slik debatt pågikk.

\section{Diskusjon}

Informantenes beskrivelser av barnehagehverdagen i Nicaragua ga meg indikasjoner på hvor sterkt de distanserte seg fra målrettet læring/undervisning i barnehagen. Deres vektlegging av lek, anerkjennelse og medvirkning viste at de knyttet sin profesjonelle identitet til tradisjonell nordisk barnehagepedagogikk (jf. Alvestad, 2010). Fagdiskursene innen denne tradisjonen ble brukt til å skape kontraster mellom norske og nicaraguanske barnehagelæreridentiteter. Informantene konstruerte identiteter ved å anerkjenne barns rett til å leke og ved å ta avstand fra at undervisning skulle gå på bekostning av leketid (jf. Pettersvold \& Østrem, 2012; Sundsdal \& Øksnes, 2015). Analysen viser hvordan slike standpunkt ble autoriserte ved å dikotomisere norske og nicaraguanske læringsmetoder.

Norsk barnehagelærerutdanning er forankret i norsk/nordisk pedagogikk- og barnehageforskning. Forutsatt at Vik og Hausstätter (2014) har rett i at norsk pedagogikklitteratur først og fremst kritiserer tidlig innsats, og at pedagogiske forskere beskriver nye læringsmetoder som en «utenlandsk» trussel mot norsk barnehagetradisjon (se Barnehageopprop, 2010, Pettersvold \& Østrem, 2012, Sundsdal \& Øksnes, 2015), er det likevel ikke overraskende at informantene distanserte seg fra undervisning. Slik jeg forstår Larsen og Slåtten (2014), er det dette resultatet jeg kunne forvente å få.

Larsen og Slåtten fikk imidlertid uventede svar i sin undersøkelse. De gjorde kvalitative og/eller kvantitative intervjuer med norske barnehagelærere og ledere. Deres beskrivelse av barnehagelærere som styres av politisk initierte resultatmål, står i kontrast til mine informanters fremstillinger av den norske barnehagen. Sett i lys av Larsen og Slåttens (2014) artikkel og at det har vært sterke føringer for formelle 
læringsmetoder i alle senere års planer (Arnesen, 2012), finner jeg det interessant at mine informanter ikke beskrev politisk styring og formelle læringsmetoder/undervisning som en del av barnehagevirkeligheten i Norge. På den annen side er det verdt å merke seg at Larsen og Slåtten intervjuet erfarne barnehagelærere og ledere, mens jeg intervjuet studenter. Sannsynligvis vil flere av mine informanter som nå jobber som barnehagelærere, erfare at nye oppgaver tar opp en stor del av arbeidstiden deres.

Jeg går uansett ut ifra at mine informanter var godt orienterte om hva som skjer i norske barnehager. De hadde gjennomført obligatorisk studentpraksis og hatt ordinært arbeid i norske barnehager i kortere eller lengre perioder. Pensum og forelesningen jeg tok lydopptak av, sannsynliggjør at de kjente til debatten om tidlig innsats, formelle læringsmetoder og politisk styring av norske barnehager. En mulig grunn til at dette ikke ble tema i intervjuene, er at det politiske presset for å innføre undervisning blir sett på som et forbigående og «unorsk» fenomen (Søreide, 2007). Day (2002) hevder at etter hvert som nye metoder blir innført i USA, må lærerstudenter tilegne seg kompetanse i å bruke formelle læringsstrategier for å lykkes som lærere. En grunn til at informantene mente at undervisning ikke blir brukt i norske barnehager, kan være at de sammenlignet Norge med land der formelle læringsmetoder på barnehagenivå har blitt brukt over lengre tid, for eksempel i USA, Australia og Storbritannia (Sachs, 2001; Day, 2002; Alvestad, 2010; Cellar \& Lingard, 2014).

Ifølge Sachs (2001) førte moderniseringen av utdanningssystemet i Australia til en opphetet debatt. Det ble stilt spørsmål ved om læreryrket kunne regnes som en profesjon. Hun skriver at enkelte debattanter betraktet lærerens profesjonsstatus som et hinder for offentlig regulering av skolens oppgaver. Informantene kan ha erfart at politisk styring og innføringen av de nye oppgavene ikke har fått like store konsekvenser i Norge som i land de sammenligner med. Når informantenes opplevelse av norsk barnehagevirkelighet ble satt opp imot den nicaraguanske, ble muligens det som gjøres av formelle læringsmetoder i Norge sett på som ubetydelig.

Dette kan bety at nicaraguansk undervisning ble et symbol på forskjellen mellom norske og utenlandske barnehagelærere generelt. Informantene distanserte seg trolig fra nicaraguanske barnehagelærere som bruker undervisning for ikke å «gi opp» sin identitet på samme måte som de, i Norge (Larsen \& Slåtten, 2014), eller utenlands (Day, 2002), som ønsker tidlig innsats og nye læringsmetoder velkomne. Det er mulig at informantene ikke fokuserte på likheter mellom egne og nicaraguanske metoder fordi det ville gjort kontrastene mellom oss og de andre utydelige (jf. Smith, 1978; Barth, 1998; Fangen, 2006). Med andre ord ville beskrivelser av formelle læringsmetoder og politisk styring i norske barnehager vært malplassert materie, det vil si i uoverensstemmelse med klassifiseringssystemene de brukte (Douglas, 1966).

Forskjellene mellom Charlottes intervju og mine var små; dette kan tyde på at instruksene jeg fikk under intervjuene også ble brukt internt i studentgruppen. Jeg fortolker informantenes preferanse for lek som at de samlet seg om diskurser de ble instruerte, og instruerte hverandre, til å forsvare (jf. Trede \& McEwen, 2012). Store omskiftninger i samfunnet, for eksempel i arbeidsforholdene, kan, ifølge Alvesson m.fl. (2008), øke intensiteten i identitetsarbeidet. Det at undervisning som foregår i 


\section{Ole Erik Klinge}

norske barnehager ikke ble nevnt i intervjuene, kan forstås som en passiv motstand mot endringer. Omfavnelsen av tradisjonell pedagogikk og lek ble så den aktive delen av identitetsarbeidet.

Det vesentligste arbeidet med å konstruere instruksene og autorisere diskursene informantene brukte, var sannsynligvis gjort på forhånd (Smith, 1978). Dette arbeidet finner man spor etter i rammeplanen for barnehagens innhold og oppgaver (Kunnskapsdepartementet, 2011), pensumlitteratur, forelesninger, avisdebatter, kampanjer og læreplaner (jf. Søreide, 2007). Jeg forstår intervjuene som både resultat og del av denne typen arbeider.

\section{Metodens styrke og svakheter}

Jeg kunne valgt å utfordre dikotomien norsk lek versus nicaraguansk undervisning ved å hevde at man bruker formelle læringsmetoder også i norske barnehager. Jeg kunne satt spørsmålstegn ved måtene de definerte lek på; observerte de ingen aktiviteter i de lokale barnehagene som tilsvarte lek i norsk versjon? Instruksene jeg har beskrevet i analysen, ledet meg til å unngå slike responser (jf. Smith, 1978). Dette kan forstås som en svakhet ved undersøkelsen fordi jeg ikke gikk i dybden for å få vite hvordan informantene erfarte debatter om lek, formelle læringsmetoder og politisk styring i Norge (Smith, 2005). På den annen side ønsket jeg at de, innenfor visse rammer, selv skulle styre dialogen. Hvis jeg oftere hadde ledet intervjuene inn på begrensede temaer, ville jeg mistet muligheter til å identifisere hvilke erfaringer informantene ønsket å formidle, og kanskje viktigst: hvilke diskurser de valgte, og hvilke de utelot.

Jeg valgte mine fremgangsmåter for å sette meg inn i arbeidsprosesser som dannet profesjonelle identiteter (Alvesson m.fl., 2008). Jeg brukte lærdommen dette ga meg, sammen med mine forforståelser og sosiologisk teori, til å fortolke intervjuene (Smith, 1978). Slik jeg ser det, er det min deltakelse i arbeidet og instruksene jeg fikk som gjør mine subjektive fortolkninger troverdige (Smith, 1978).

\section{Oppsummering og konklusjon}

Jeg har argumentert for at mine informanter brukte tradisjonelle pedagogikkdiskurser og begreper til å konstruere dikotomier, først og fremst lek $i$ norsk versjon versus nicaraguansk undervisning. Ved å knytte lek til positivt ladede begreper som anerkjennelse og medvirkning, og konstruere undervisning som en motsetning til leken, viste de at de identifiserte seg sterkt med lek som læringsmetode. De brukte tradisjonelle barnehagediskurser på denne måten til å autorisere en forestilling om en felles norsk profesjonsidentitet. Trolig ble få av dikotomiene til der og da, mens jeg intervjuet, men hadde sitt utspring i diskurser som er skapt, og gjenskapes, i noenlunde samme form av det profesjonelle fellesskapet informantene sosialiseres inn i (Søreide, 2007). Det trenger derfor ikke nødvendigvis å ligge noe bevisst eller strategisk bak deres valg av diskurser og dikotomier.

Et gjennomgående trekk ved intervjuene er at hjemlige debatter om formelle læringsmetoder, tidlig innsats og politisk styring ble utelatt fra sammenligninger av norske og nicaraguanske barnehager. Hvorfor dette skjedde, beror sannsynligvis på en 
lang rekke faktorer. Intervjuene indikerer at informantene ikke oppfattet politisk styring og formelle læringsmetoder i norsk versjon som omfattende, sett $\mathrm{i}$ en internasjonal sammenheng.

\section{Biografi}

Ole Erik Klinge er stipendiat ved Avdeling for lærerutdanning ved Høgskolen i Østfold. Han er Cand. Polit. i sosialantropologi og Phd-student ved Institutt for sosiologi og samfunnsgeografi ved Universitetet i Oslo.

\section{Referanser}

Alvesson, M., Aschcraft, K. L. \& Thomas, R. (2008). Identity Matters: Reflections on the Construction of Identity Scholarship in Organization Studies. Organization, 15(1), 5-28.

Alvestad, M. (2010). Perspektiver på læring i barnehagen. I Ø. Kvello (Red.), Barnas barnehage, 1 Målsettinger, føringer og rammer for barnehagen (s. 101-117). Oslo: Gyldendal Akademisk.

Andresen, R. (2012). Ideologiske spenninger mellom inkluderingspolitikk og barnehagens inkluderende praksis. I A. L. Arnesen (Red.), Inkludering (s. 101-123). Oslo: Universitetsforlaget.

Arnesen, A. L. (2012). Inkludering i det utdanningspolitiske barnehagelandskapet. I A. L. Arnesen (Red.), Inkludering (s. 56-76). Oslo: Universitetsforlaget.

Barnehageopprop (2010). Nei til kartlegging av alle barn. Hentet fra https://sites.google.com/site/barnehageop prop/

Barth, F. (1998). Introduction. I F. Barth (Red.), Ethnic groups and boundaries: The social organization of culture difference (s. 9-39). Long Grove: Waveland Press.

Cellar, S. \& Lingard, B. (2014). The OECD and the expansion of PISA: New global modes of governance in education. British Educational Research fournal, 40(6), 917-936.

Day, C. (2002). School reform and transitions in teacher professionalism and identity. International fournal of Educational Research, 37(8), 677-692.

Douglas, M. (1966). Purity and danger: An analysis of the concepts of pollution and taboo. New York: Pantheon.

Emilson, A. \& Folkesson, A. M. (2006). Children's participation and teacher control. Early child development and care, 176(3-4), 219-238.

Eriksen, T. H. (1995). We and Us: Two Modes of Group Identification. Fournal of Peace Research, 32(4), $427-436$.

Fangen, K. (2006). Assimilert, hybrid eller inkorporert i det etniske? Tilpasning og identifikasjon blant somaliere i Norge. Sosiologisk tidsskrift, 14(1), 4-33.

Freire, P. (2000). Pedagogy of the oppressed. London: Bloomsbury Publishing.

Heggen, K. (2008). Profesjon og identitet. I A. Molander \& L. I. Terum (Red.), Profesjonsstudier (s. 321-332). Oslo: Universitetsforlaget.

Høgskolen i Vestfold (2011). Fag- og studieplan i flerkulturell pedagogikk med studiested Nicaragua 2012.

Kangas, J., Ojala, M. \& Venninen, T. (2015). Children's Self-Regulation in the Context of Participatory Pedagogy in Early Childhood Education. Early Education and Development, 26(5-6), 847-870.

Kunnskapsdepartementet (2006). Rammeplan for barnehagens innhold og oppgaver. Oslo: Kunnskapsdepartementet.

Kunnskapsdepartementet (2007). St.Meld. nr. 16, Og ingen sto igjen. Tidlig innsats for livslang lering. Oslo: Kunnskapsdepartementet.

Kunnskapsdepartementet (2011). Rammeplan for barnehagens innhold og oppgaver. Oslo: Kunnskapsdepartementet.

Larsen, A. K. \& Slåtten, M. V. (2014). Mot en ny pedagogisk lederrolle og lederidentitet? Nordisk Barnehageforskning, 7(5), 1-19.

Pettersvold, M. \& Østrem, S. (2012). Mestrer, mestrer ikke - jakten på det normale barnet. Otta: Res Publica.

Sachs, J. (2001). Teacher professional identity: competing discourses, competing outcomes. fournal of Education Policy, 16(2), 149-161.

Sandvik, N. (2016). Småbarnspedagogikkens komplekse komposisjoner i et sammenvevd og uoversiktlig psykologisk, pedagogisk, politisk og økonomisk felt. I N. Sandvik (Red.), Småbarnspedagogikkens komplekse komposisjoner: Lering møter filosofi (s. 9-31). Bergen: Fagbokforlaget.

Smith, D. E. (1978). K is Mentally Ill': the Anatomy of a Factual Account. Sociology, 12(1), $23-53$. 


\section{Ole Erik Klinge}

Smith, D. E. (2005). Institutional Ethnography. A Sociology for People. Oxford: Alta Mira Press.

Steinnes, G. S. (2010). Frå utdanning til yrke: Førskulelæraren som profesjonell aktør? I T. L. Hoel, G. Engvik \& B. Hanssen (Red.), Ny som lerer: Sjansespill og samspill (s. 115-135). Trondheim: Tapir Akademisk Forlag.

Steinsholt, K. \& Øksnes, M. (2003). Kunsten å fange øyeblikket. Norsk Pedagogisk Tidsskrift, 1(2), $56-68$.

Sullivan, P. (2012). Qualitative Data Analysis. London: Sage Publications.

Sundsdal, E. \& Øksnes, M. (2015). Til forsvar for barns spontane lek. Nordisk tidsskrift for pedagogikk og kritikk, 1, 1-11. http://dx.doi.org/10.17585/ntpk.v1.89

Søreide, G. E. (2007). Narrative construction of teacher identity. (doktoravhandling). University of Bergen, Norway.

Trede, F. \& McEwen, C. (2012). Developing a critical professional identity: Engaging self in practice. I J. Higgs, R. Barnett, S Billett, M. Hutchings \& F. Trede (Red.), Practice-Based Education: Perspectives and Strategies (s. 27-40). Rotterdam: Sense Publishers.

Utdannings-, kultur-, and idrettsministeriet (2004). Overordnet plan: Lære hva man kan gjøre sammen med barn i barnehager og kommunale sentre. Managua: Utdannings-, kultur-, og idrettsministeriet.

Utenriksdepartementet (2015). Landsider: Nicaragua. Hentet fra www.landsider.no/land/nicaragua/fakta

Vassenden, A., Thygesen, S.B. Bayes, M. Alvestad \& G. Abrahamsen (2011). Barnehagens organisering og strukturelle faktorers betydning for kvalitet. Stavanger: Rapport IRIS 2011/029.

Vik, S. \& Hausstätter, R. S. (2014). Fra «Early Intervention» til tidlig innsats: Utfordringer ved adopsjon av amerikanske intervensjonsprogrammer til norsk pedagogikk. Spesialpedagogikk, 6(14), 45-57. 